International Journal of Environment, Agriculture and Biotechnology
Vol-6, Issue-6; Nov-Dec, 2021
J Journal Home Page Available: https://ijeab.com/
Journal DOI: $10.22161 /$ ijeab

\title{
The Effect of Trichoderma Biourine Application on Growth, Occurrence of Fusarium Wilt Disease and Yield of Several Shallot Varieties
}

\author{
I Made Sudantha ${ }^{1 *}$, Suwardji ${ }^{2}$
}

\begin{abstract}
${ }^{1}$ Agroecotechnology Study Program, Faculty of Agriculture University of Mataram, Mataram Indonesia
${ }^{2}$ Soil Science Study Program, Faculty of Agriculture University of Mataram, Mataram Indonesia

Email:* sudantha@unram.ac.id (Corresponding Author), suwardji@unram.ac.id
\end{abstract}

Received: 11 Oct 2021; Received in revised form: 30 Nov 2021; Accepted: 08 Dec 2021; Available online: 13 Dec 2021

C2021 The Author(s). Published by Infogain Publication. This is an open access article under the CC BY license

(https://creativecommons.org/licenses/by/4.0/).

\begin{abstract}
Biourine is a liquid fertilizer that contains complete elements, namely nitrogen, phosphorus, and potassium in small amounts as well as zinc, iron, manganese, and copper. Biourine can provide an increase in plant yields that is almost the same as plant fertilizers, besides that it can control Fusarium wilt disease. This study aims to determine the effect of Trichoderma biourin application on plant growth, Fusarium wilt disease and onion yield. The research was conducted using an experimental method in Senteluk Village, Batu Layar District, West Lombok Regency, West Nusa Tenggara using a Split Plot Design consisting of 2 factors. As the main plot, the shallot varieties consist of three levels, namely Bali Karet, Ampenan and Keta Monca, while as a sub-plot, the Trichoderma biourin application method consists of four levels, namely: without biourine, spraying the soil surface, spraying seed tubers, and spraying on plants 21 days after planting. The treatment was a combination of shallot varieties and Trichoderma biourine application method, each of which was repeated three times, so there were 36 experimental units. The results showed that: (a) The application of liquid biourine by spraying the soil surface, spraying seed tubers and spraying on plants 21 days after planting could increase the growth and yield of shallot bulbs. (b) The Bali Karet shallots varieties are more resistant to Fusarium wilt disease when compared to Ampenan and Keta Monca varieties.
\end{abstract}

Keywords-Biourine, Trichoderma, Fusarium wilt disease, shallot, Bali Karet.

\section{INTRODUCTION}

Shallots (Allium cepa var. ascalonicum). is a tuber vegetable that is quite popular among the public, in addition to its high economic value, red onion also functions as a flavoring and can also be used as an ingredient in traditional medicine or other pharmaceutical raw materials [1].

The province of West Nusa Tenggara or NTB is one of the centers of shallot production after Central Java, East Java and West Java. Shallot production in NTB from 2015-2019 has increased. NTB shallot production in 2015 was 160,201 tons with a harvested area of 14,524 ha, in 2016 as many as 211,804 tons with a harvested area of 19,275 ha, in 2017 as many as 195,458 tons with a harvested area of 17,904 ha, in 2018 as many as 212,885 tons with a harvested area of 19,341 ha, and in 2019 as many as 188,255 tons with an area of 16,688 ha. In 2017 the productivity of shallots in NTB decreased to 10.92 tons/ha whereas previously it was 11.03 tons/ha [2]. The productivity of shallots is still relatively low compared to the results of the study, which reached 15 tons/ha [3].

One of the causes of a decrease in the productivity of shallots in NTB is Fusarium wilt disease caused by the fungus Fusarium oxysporum f. sp. cepae, the use of shallot seeds that are susceptible to Fusarium and poor quality seeds, as well as Fusarium wilt disease control techniques that still rely on the use of fungicides [3]. 
The varieties of shallots grown by farmers in NTB vary depending on the area where they are planted, for example, in Sembalun Bumbung Village, East Lombok Regency, farmers mostly plant the Bali Karet variety, in Senteluk Village, West Lombok Regency, farmers plant Ampenan and Super Philip varieties, in Santong Village, Lombok Regency. In the north, farmers plant Ampenan and Super Philip varieties, in Rada Village, Bima district, farmers plant Keta Monca and Super Philip varieties. The results of field observations turned out that all shallot varieties planted by farmers were attacked by the fungus $F$. oxysporum which causes wilt disease [3].

Fungal attack F. oxysporum f. sp. cepae can cause shallots to wilt quickly, leaves turn yellow and twist and the base of the stem rots. Fusarium wilt disease has caused damage and reduced tuber yield by up to 50\% [4]. Attacks on plants if symptoms like this are found, then the plants are removed and destroyed [5]. Fusarium wilt disease develops in shallot planting centers in NTB starting from West Lombok, East Lombok, Sumbawa, and Bima which causes damage and reduces the yield of tubers by more than $45 \%$ [6].

Fusarium wilt disease on shallots is very difficult to control, because this fungus has chlamydospores which are structures that can survive in the soil as a saprophyte for about three to four years even without a host plant [7]. Thus, it is necessary to find an alternative to control Fusarium wilt that is effective and environmentally friendly. One control technique that has good prospects is biological technology using biourine fermented with Trichoderma fungus and the use of shallots varieties that have induced resistance to Fusarium wilt disease.

Biourine is a liquid fertilizer that contains complete elements, namely nitrogen, phosphorus, and potassium in small amounts as well as zinc, iron, manganese, and copper. Biourin can provide an increase in plant yields that is almost the same as plant fertilizers [8]. One of the microbes used for biourin fermentation is Trichoderma spp. Biourine containing Trichoderma spp. able to stimulate the growth of mustard greens when compared to mustard plants without being given biourine, besides that biourine containing Trichoderma spp., has the potential to protect mustard plants from clubroot disease (Plasmodiophora brassicae), this disease is an important disease in mustard and cabbage plants [9].

Trichoderma fungi isolated from the rhizosphere of shallot plants were reported to be effective in controlling the fungus $F$. oxysporum f. sp. cepae in vitro with inhibition percentage of $45 \%$ [10]. The fungus T. harzianum in suppressing the growth of the fungus $F$. oxysporum $\mathrm{f}$. sp. cepae through the mechanism of competition for space and nutrients, mycoparasites and antibiosis [11]. In a greenhouse experiment, it was reported that the fungus $T$. harzianum was able to inhibit the incidence of Fusarium wilt disease in shallots up to $75 \%$ [12].

Several reports explain that the Trichoderma fungi is not only used for biourine fermentation, but also for the fermentation of other materials. The fungus $T$. harzianum used to ferment liquid biocompost from cow dung applied to vanilla plants can control Fusarium wilt disease [10]. The fungus T. harzianum applied to soybeans could inhibit the development of Fusarium wilt disease [13]. The fungus T. harzianum can control Fusarium wilt disease on banana plants [10]. Fusarium wilt disease in maize can be inhibited by the fungus $T$. harzianum [14]. The fungus $T$. harzianum is effective in controlling Fusarium wilt disease in soybeans [15]. The fungus $T$. harzianum was able to suppress Fusarium wilt disease in shallots [16]. The use of the fungus $T$. harzianum in the form of a tablet bioactivator formulation of $15 \mathrm{~g} /$ pot effectively controlled the fungus $F$. oxysporum f.sp. cepae on shallots reached $42.26 \%$ [17] and was able to increase plant growth and yield of shallots [18].

Induced resistance is the resistance of plants to pathogen infection because plants have been infected by other microorganisms before, both of the same type or of other types. Induced resistance can also occur after plants are inoculated early with biotic elicitors (avirulent, nonpathogenic, saprophytic microorganisms) [19]. Fusarium wilt control using onion varieties that have induced resistance have good prospects. The results of the preliminary study showed that the varieties of Bali Karet, Ampenan varieties, Keta Monca varieties, Bima Brebes and Super Philip varieties induced with the fungus $T$. harzianum caused immunity to Fusarium wilt disease [12] and induced resistance to Fusarium wilt disease [16].

The effect of Trichoderma biourine application in increasing growth and yield of several varieties of shallots in the field has never been studied. Therefore, a research was conducted on "The Effect of Trichoderma Biourine Application on the Growth and Yield of Three Shallot Varieties".

\section{METHOD}

\section{Experimental Design}

The study used an experimental method in Senteluk Village, Batu Layar District, West Lombok Regency, West Nusa Tenggara using a Split Plot Design consisting of 2 factors. As the main plot, the shallot varieties consist of three levels, namely Bali Karet, Ampenan and Keta Monca, while as a sub-plot, the 
Trichoderma biourine application method consists of four levels, namely: without biourine, soil surface spraying, seed tuber spraying, and spraying on plants 21 days after planting. The treatment was a combination of shallot varieties and Trichoderma biourine application method, each of which was repeated three times, so there were 36 experimental units.

\section{Experiment Execution}

The production of Trichoderma biourine is carried out as follows: cow urine is collected in a holding tank. Furthermore, the standard solution of Trichoderma was put into a urine reservoir, then closed the fermentation container, and incubated for 4 weeks. Open the lid of the container once a week and stir for 15 minutes. After 4 weeks, the circulation was carried out using a ladder for 24 hours to remove the ammonia element which is pathogenic for plants. Trichoderma fermented biourin is ready to be applied to shallot plants.

The shallot seeds used were the Bali Karet, Keta Monca and Ampenan varieties purchased from seed breeders. Shallot seeds that are good to use are healthy and quality seeds with a shelf life of 2 months and there are visible growing points on the roots. The day before planting the seeds are cut off about part.

Tillage was carried out using a hoe to level the soil and making experimental plots with a size of $2 \mathrm{~m} \times 4 \mathrm{~m}$ for each treatment plot. After processing the soil, basic fertilization is carried out using Phonska fertilizer of 100 $\mathrm{kg} / \mathrm{ha}$ (50\% of the recommendation). Basic fertilizer application was carried out by immersing it next to the planting hole, then the experimental plot was covered with plastic mulch.

The application of biourine was carried out according to the treatment, namely: by spraying the soil surface before installing plastic mulch, spraying shallot bulbs for 30 minutes, and spraying shallot plants after 21 days. Planting is done by inserting shallot seed bulbs into a hole with a depth of $2 \mathrm{~cm}$ and the hole is covered again with soil. Planting is done with a spacing of $20 \times 20 \mathrm{~cm}$.

\section{Variable Observation}

Observation of disease incidence was carried out by counting the number of wilted plants, observations were made from the age of 7 days after planting (DAP) until the shallots plants were 35 DAP. Disease incidence (\%) is calculated using the following formula:

$\mathrm{I}=\frac{\mathrm{a}}{\mathrm{b}} \mathrm{x} 100 \%$

where :

$\mathrm{I}=$ Percentage of disease incidence

$\mathrm{a}=$ Number of plants showing disease symptoms

$\mathrm{b}=$ Total number of plants observed

Observations of growth components, namely plant height and number of leaves of shallot plants were carried out from the age of 7 DAP to 35 DAP. Observations of yield components were carried out at harvest, namely at the age of more than 70 DAP. Observation of harvested dry shallot bulb weight was carried out by weighing the weight of bulbs at harvest per plot and then converted to hectares. Observation of the weight of stored dry shallots was carried out by weighing all parts of the plant in a dry state or after being stored in a wind-dried state for one month.

\section{Data Analysis}

Observational data were analyzed using Diversity Analysis with a significance level of 5\% and further tested using the Honest Significant Difference test or HSD at the same significant level.

\section{RESULT AND DISCUSSION}

The results of the analysis of variance showed that the treatment of Trichoderma biourine application and shallot varieties were significantly different, while the interactions did not show significant differences in the incidence of Fusarium wilt disease, plant height growth and the number of shallots and shallot yields, namely the number of tillers, dry shallot bulb weight. harvest and weight of dry shallot bulbs stored.

\section{Occurrence of Fusarium Wilt Disease on Shallots}

The results of further tests on the effect of Trichoderma biourine application on the incidence of Fusarium wilt disease at the age of 7 DAP to 35 DAP using the $5 \%$ BNJ test are presented in Table 1. 
Table 1. The Effect of Trichoderma Biourine Application on the Occurrence of Fusarium Wilt Disease in Shallots at the age of 7 DAP to 35 DAP

\begin{tabular}{|l|l|c|c|c|c|c|}
\hline \multirow{2}{*}{ No. } & How to Apply & \multicolumn{5}{|c|}{ Occurrence of Fusarium Wilt Disease $(\%)$} \\
\cline { 3 - 7 } & & 7 DAP & 14 DAP & 21 DAP & 28 DAP & 35 DAP \\
\hline 1. & Without biourine & $18.40 \mathrm{a}^{1)}$ & $41.40 \mathrm{a}^{1)}$ & $46.00 \mathrm{a}^{1)}$ & $49.00 \mathrm{a}^{1)}$ & $50.00 \mathrm{a}^{1)}$ \\
\hline 2. & Ground surface spraying & $0.00 \mathrm{~b}$ & $3.80 \mathrm{~b}$ & $7.20 \mathrm{~b}$ & $9.60 \mathrm{~b}$ & $10.00 \mathrm{~b}$ \\
\hline 3. & Spraying of seed tubers & $0.00 \mathrm{~b}$ & $3.80 \mathrm{~b}$ & $8.30 \mathrm{~b}$ & $9.20 \mathrm{~b}$ & $9.50 \mathrm{~b}$ \\
\hline 4. & $\begin{array}{l}\text { Spraying plants aged 21 } \\
\text { days }\end{array}$ & $0.00 \mathrm{~b}$ & $3.90 \mathrm{~b}$ & $7.60 \mathrm{~b}$ & $9.10 \mathrm{~b}$ & $9.40 \mathrm{~b}$ \\
\hline
\end{tabular}

Notes: ${ }^{1)}$ The numbers in each column followed by the same letter are not significantly different.

In Table 1, it can be seen that the application of Trichoderma biourine significantly affected the incidence of disease in shallot plants at the age of 7 DAP to 35 DAP. Trichoderma biourine which was applied by spraying the soil surface, spraying seed tubers and spraying on plants after 21 days could reduce the incidence of Fusarium wilt disease, while in control or without Trichoderma biourine treatment the incidence of Fusarium wilt at 35 DAP reached $50 \%$.

The low incidence of Fusarium wilt disease in shallots after the application of Trichoderma biourine was due to the population of Trichoderma spp. in the rhizosphere increased markedly. The results of observations of the population of Trichoderma fungi in the rhizosphere showed an increase in the population in all biourine treatments, namely an average of $43.00 \times 10^{3}$ propagules/g soil, while in the control there was no Trichoderma spp. [20]. The fungus Trichoderma in soil is able to inhibit the development of disease-causing pathogens by means of competition both in terms of space and nutrients. The fungus Trichoderma can use various nutrient sources for growth by destroying cellulose, starch, lignin, and other soluble compounds such as protein and sugar [21]. In addition, Trichoderma can also inhibit the growth of pathogenic spores and hyphae with its ability to produce furonan group antibiotics [22]. The use of biofungicides fermented with Trichoderma spp. a minimum of $5 \mathrm{ml} /$ plant can control Fusarium wilt disease through the mechanism of space competition, mocoparasites and antibiosis. [16].

\section{The Effect of Trichoderma Biourine Application on}

\section{Shallot Plant Growth}

The results of further tests on the effect of Trichoderma biourine application on plant height and number of shallots at the age of 7 DAP to 35 DAP using $5 \%$ BNJ are presented in Tables 2 and 3.

Table 2. The Effect of Trichoderma Biourine Application on Shallot Plant Height at the age of 7 DAP to 35 DAP

\begin{tabular}{|l|l|c|c|c|c|c|}
\hline \multirow{2}{*}{ No. } & How to Apply & \multicolumn{5}{|c|}{ Shallot Plant Height $(\mathrm{cm})$} \\
\cline { 3 - 6 } & & 7 DAP & 14 DAP & 21 DAP & 28 DAP & 35 DAP \\
\hline 1. & Without biourine & $3.50 \mathrm{a}^{1)}$ & $15.50 \mathrm{a}^{1)}$ & $18.80 \mathrm{a}^{1)}$ & $20.10 \mathrm{a}^{1)}$ & $24.30 \mathrm{a}^{1)}$ \\
\hline 2. & Ground surface spraying & $7.80 \mathrm{~b}$ & $21.60 \mathrm{~b}$ & $30.80 \mathrm{~b}$ & $36.10 \mathrm{~b}$ & $37.00 \mathrm{~b}$ \\
\hline 3. & Spraying of seed tubers & $7.90 \mathrm{~b}$ & $22.50 \mathrm{~b}$ & $31.30 \mathrm{~b}$ & $36.30 \mathrm{~b}$ & $38.00 \mathrm{~b}$ \\
\hline 4. & $\begin{array}{l}\text { Spraying plants aged 21 } \\
\text { days }\end{array}$ & $8.20 \mathrm{~b}$ & $23.30 \mathrm{~b}$ & $31.40 \mathrm{~b}$ & $36.60 \mathrm{~b}$ & $38.40 \mathrm{~b}$ \\
\hline
\end{tabular}

Table 3. The Effect of Trichoderma Biourine Application on the Number of Leaf Shallots at the age of 7 DAP to 35 DAP

\begin{tabular}{|l|l|c|c|c|c|c|}
\hline \multirow{2}{*}{ No. } & How to Apply Trichoderma & \multicolumn{5}{|c|}{ Number of Leaves (strands) } \\
\cline { 3 - 7 } & & 7 DAP & 14 DAP & 21 DAP & 28 DAP & 35 DAP \\
\hline 1. & Without biourine & $4.30 \mathrm{a}^{1)}$ & $13.60 \mathrm{a}^{1)}$ & $18.80 \mathrm{a}^{1)}$ & $20.50 \mathrm{a}^{1)}$ & $23.23 \mathrm{a}$ \\
\hline 2. & Ground surface spraying & $7.80 \mathrm{~b}$ & $20.70 \mathrm{~b}$ & $28.70 \mathrm{~b}$ & $33.70 \mathrm{~b}$ & $35.00 \mathrm{~b}$ \\
\hline 3. & Spraying of seed tubers & $7.90 \mathrm{~b}$ & $20.80 \mathrm{~b}$ & $28.80 \mathrm{~b}$ & $33.90 \mathrm{~b}$ & $35.40 \mathrm{~b}$ \\
\hline 4. & Spraying plants aged 21 days & $7.90 \mathrm{~b}$ & $20.90 \mathrm{~b}$ & $29.10 \mathrm{~b}$ & $34.40 \mathrm{~b}$ & $35.60 \mathrm{~b}$ \\
\hline
\end{tabular}


From Tables 2 and 3 it is known that the method of application of Trichoderma biourine significantly affected plant height and number of shallots. The plant height and the highest number of scallions began to be seen in all Trichoderma biourine applications.

From the results of this study, it can be said that all methods of biourin application can increase plant height and the number of leaves of shallot plants. The growth of plant height and number of leeks after the application of Trichoderma biourine is suspected because the Trichoderma fungus contained in the biourin has a role in stimulating ethylene in plant tissues so as to stimulate plant vegetative growth [11]. The fungus $T$. harzianum can stimulate seed germination and plant growth [23]. Ethylene is a hormone produced by the fungus Trichoderma spp. can stimulate plant flowering [24]. Treatment of the fungus T. harzianum on soybean plants can stimulate plant growth so as to increase plant height and number of plant leaves [21]. Trichoderma spp. able to stimulate plants to form the hormones gibberellin acid (GA3), Indolasetic acid (IAA), and benzylaminopurine (BAP) so that plant growth such as plant height and number of leaves is more and is healthy, tough and affects plant resistance to disease. Furthermore, gibberellins and auxin hormones also play a role in root and stem elongation, tuber formation and increase plant development [22].

\section{The Effect of Trichoderma Biourine Application on Shallot Yield}

The results of further tests on the effect of the application of Trichoderma biourine on the number of tillers of shallots, the weight of harvested dried shallots and the weight of stored dried shallots using BNJ 5\% are presented in Table 4.

Table 4. The Effect of Trichoderma Biourin Application on Number of Tillers, Weight of Harvested Dried Shallot Bulbs and Dried Shallot Bulbs Weight of Stored

\begin{tabular}{|l|l|c|c|c|}
\hline No. & $\begin{array}{l}\text { How to Apply Trichoderma } \\
\text { Biourine }\end{array}$ & $\begin{array}{c}\text { Weight of Harvested } \\
\text { Dried Bulbs (tons/ha) }\end{array}$ & $\begin{array}{c}\text { Dry Bulbs Weight Save } \\
\text { (tons/ha) }\end{array}$ \\
\hline 1. & Without biourine & $6.70 \mathrm{a}^{1)}$ & $6.80 \mathrm{a}^{1)}$ & $4.50 \mathrm{a}^{1)}$ \\
\hline 2. & Ground surface spraying & $11.80 \mathrm{~b}$ & $13.90 \mathrm{~b}$ & $12.30 \mathrm{~b}$ \\
\hline 3. & Spraying of seed tubers & $11.90 \mathrm{~b}$ & $14.20 \mathrm{~b}$ & $12.40 \mathrm{~b}$ \\
\hline 4. & $\begin{array}{l}\text { Spraying plants aged } 21 \\
\text { days }\end{array}$ & $12.20 \mathrm{~b}$ & $14.40 \mathrm{~b}$ & $12.60 \mathrm{~b}$ \\
\hline
\end{tabular}

Table 4 shows the number of tillers, the weight of harvested dry shallots, and the lowest weight of harvested dried shallots in the control or without using biourine. This indicates that the application of Trichoderma biourine can increase the number of tillers of shallot, the weight of harvested dry shallots, and the weight of harvested dry shallots.

The increase in the number of shallot tillers, harvested dry shallot bulb weight and stored dry shallot tuber weight after application of Trichoderma biourine was thought to be due to the role of this fungus in stimulating growth and increasing yield. It was reported that the fungus $T$. harzainum in the rhizosphere or plant root areas secretes ethylene which is diffused into the plant body through xylem which plays a role in promoting generative growth [11]. Treatment with conidia of $T$. viride and $T$. koningii fungi for controlling blight on strawberry plants was able to stimulate early flowering [25]. Ethylene is a hormone produced by the fungus Trichoderma spp. can stimulate flowering in plants [24]. Treatment of the fungus T.harzianum on soybean plants can stimulate plant growth so as to increase yield components [21]. Trichoderma spp. can produce certain hormones to increase the weight and number of pods in soybean plants [26]. Trichoderma spp. can stimulate plants to produce hormones gibberellin acid (GA3), Indolasetic acid (IAA), and benzylaminopurine (BAP) so that plant growth becomes optimum, and affects plant resistance. Gibberellins and auxin hormones play a role in root and stem elongation, and fruit (tuber) growth and increase plant growth [27].

Several previous researchers reported the successful use of Trichoderma fungi in various formulations on various plants. The use of biaoactivators fermented with Trichoderma spp. can increase the growth and yield of shallots in dry land [28]. The use of bioactivators fermented with Trichoderma spp. can increase the induced resistance of soybean plants to plant diseases and increase the growth and yield of soybean plants [29]. Tablet and liquid bioactivator fermented with Trichoderma spp. can increase soybean plant-induced resistance to wilt disease and increase soybean growth and yield [30]. Bioactivator 
and biocompost fermented with Trichoderma spp. can increase the weight of shallot bulbs [17]. The use of Trichoderma spp. which is formulated in the form of a stimulator biocompost can increase the growth and yield of maize in dry land [31]. The use of Trichoerma spp. in the form of a liquid bioactivator formulation as much as 5 $\mathrm{ml} /$ plant can increase the growth and yield of shallots [32]. Furthermore, it was also reported that the fungus Trichoderma spp. which is formulated in the form of biocompost can increase the growth and yield of soybean plants [33]. The use of Trichoderma biochar can increase soybean yield [34]. The use of Trichoderma biocompost can increase the yield of shallots [35]. The use of Trichoderma biofungicide can control Fusarium wilt disease and increase shallots yield [36]. The application of Trichoderma liquid biofungicide can increase the weight of harvested dried shallots bulbs [37]. The use of Trichoderma fungus can increase the resistance induced by banana seedlings to Fusarium wilt disease. The use of the saprophytic fungus Trichoderma antagonist causes shallots plants to become resistant to Fusarium wilt disease.

\section{The Effect of Shallot Varieties on the Occurrence of Fusarium Wilt}

The results of further tests using BNJ 5\% the effect of shallot varieties on the incidence of Fusarium wilt disease at the age of 7 DAP to 35 DAP are presented in Table 5.

Table 5. The Effect of Shallot Varieties on the Occurrence of Fusarium Wilt Disease in Shallots at the age of 7 DAP to 35 DAP

\begin{tabular}{|l|l|c|c|c|c|c|}
\hline \multirow{2}{*}{ No. } & \multirow{2}{*}{ Shallot Varieties } & \multicolumn{5}{|c|}{ Occurrence of Fusarium Wilt Disease (\%) } \\
\cline { 3 - 7 } & & 7 DAP & 14 DAP & 21 DAP & 28 DAP & 35 DAP \\
\hline 1. & Bali Karet & 0.00 & $2.50 \mathrm{a}^{1)}$ & $4.90 \mathrm{a}^{1)}$ & $6.40 \mathrm{a}^{1)}$ & $7.70 \mathrm{a}^{1)}$ \\
\hline 2. & Ampenan & 0.00 & $3.50 \mathrm{~b}$ & $5.60 \mathrm{~b}$ & $9.50 \mathrm{~b}$ & $10.70 \mathrm{~b}$ \\
\hline 3. & Keta Monca & 0.00 & $3.70 \mathrm{~b}$ & $5.90 \mathrm{~b}$ & $9.70 \mathrm{~b}$ & $10.90 \mathrm{~b}$ \\
\hline
\end{tabular}

Notes: ${ }^{1)}$ The numbers in each column followed by the same letter are not significantly different.

In Table 5 it can be seen that shallot varieties showed different effects on Fusarium wilt disease on shallots from 14 DAP to 35 DAP. Of the three varieties of shallots tested, it turned out that the Bali Karet variety showed a lower incidence of Fusarium wilt disease than the Ampenan and Keta Monca varieties.

The difference in the incidence of Fusarium wilt in the three varieties of shallot is thought to be because genetically these three varieties have different resistance. In addition, environmental factors such as sunlight, irrigation and soil conditions also affect resistance to Fusarium wilt disease. The Bali Karet, Ampenan and
Keta Monca varieties in environmental adaptation tests at different altitude locations showed different resistance reactions to Fusarium wilt disease. The Bali Karet varieties grown in the highlands of Sembalun, the medium plains of Santong and the lowlands of Senteluk are resistant to Fusarium wilt disease [3].

\section{The Effect of Shallot Varieties on Plant Growth}

The results of further tests on the effect of shallot varieties on plant height and number of shallots at the age of 7 DAP to 35 DAP using 5\% BNJ are presented in Tables 6 and 7.

Table 6. Effect of Shallot Varieties on Shallot Plant Height at the age of 7 DAP to 35 DAP

\begin{tabular}{|l|l|c|c|c|c|c|}
\hline \multirow{2}{*}{ No. } & \multirow{2}{*}{ Shallot Varieties } & \multicolumn{5}{|c|}{ Shallot Plant Height $(\mathrm{cm})$} \\
\cline { 3 - 7 } & & 7 DAP & 14 DAP & 21 DAP & 28 DAP & 35 DAP \\
\hline 1. & Bali Karet & $7.50 \mathrm{a}^{1)}$ & $28.40 \mathrm{a}^{1)}$ & $35.70 \mathrm{a}^{1)}$ & $38.80 \mathrm{a}^{1)}$ & $40.80 \mathrm{a}^{1)}$ \\
\hline 2. & Ampenan & $6.70 \mathrm{~b}$ & $22.70 \mathrm{~b}$ & $31.80 \mathrm{~b}$ & $35.80 \mathrm{~b}$ & $37.50 \mathrm{~b}$ \\
\hline 3. & Keta Monca & $6.50 \mathrm{~b}$ & $22.50 \mathrm{~b}$ & $31.70 \mathrm{~b}$ & $35.60 \mathrm{~b}$ & $37.30 \mathrm{~b}$ \\
\hline
\end{tabular}


Table 7. The Effect of Shallot Varieties on the Number of Leaves of Shallots at the age of 7 DAP to 35 DAP

\begin{tabular}{|l|l|c|c|c|c|c|}
\hline \multirow{2}{*}{ No. } & \multirow{2}{*}{ Shallot Varieties } & \multicolumn{5}{|c|}{ Number of Shallots Leaves (pieces) } \\
\cline { 3 - 7 } & & 7 DAP & 14 DAP & 21 DAP & 28 DAP & 35 DAP \\
\hline 1. & Bali Karet & $17.50 \mathrm{a}^{1)}$ & $30.50 \mathrm{a}^{1)}$ & $35.80 \mathrm{a}^{1)}$ & $45.20 \mathrm{a}^{1)}$ & $47.20 \mathrm{a}^{1)}$ \\
\hline 2. & Ampenan & $7.50 \mathrm{~b}$ & $22.70 \mathrm{~b}$ & $28.80 \mathrm{~b}$ & $38.70 \mathrm{~b}$ & $41.50 \mathrm{~b}$ \\
\hline 3. & Keta Monca & $7.40 \mathrm{~b}$ & $22.50 \mathrm{~b}$ & $28.60 \mathrm{~b}$ & $38.50 \mathrm{~b}$ & $39.90 \mathrm{~b}$ \\
\hline
\end{tabular}

From Tables 6 and 7 it is known that shallot varieties show different effects on plant height and the number of shallots on plants from the age of 7 DAP to 35 DAP. The Bali Karet variety showed higher plants than the Ampenan and Keta Monca varieties, while the Ampenan and Keta Monca varieties did not show a significant difference.

The occurrence of differences in plant height and number of leaves of shallot plants is thought to be due to genetic factors of each variety used, in addition to the adaptability of the variety to the environment such as sunlight, irrigation, rain intensity and soil conditions. Differences in plant growth are morphological adaptability, which in turn will affect the growth and yield of a plant [40]. The occurrence of variations in a plant can be caused by environmental influences and genetic factors. Differences in environmental conditions cause variations that can determine the final appearance of a plant [41]. The average plant height of the Bali Karet variety was 50-60 cm higher than the Ampenan and Keta Monca varieties, namely 26$45 \mathrm{~cm}$ and $26-46 \mathrm{~cm}$. The number of leaves of the Bali Karet variety is 50-55 more than the Ampenan variety, which is 45-50 and the Keta Monca variety is 17-47 strands [3]

\section{Effect of Shallot Varieties on Yield}

The results of further tests on the effect of shallot varieties on plant height and number of tillers, weight of harvested dried shallots and weight of stored dried shallots using HSD 5\% are presented in Table 8.

Table 8. Effect of Shallot Varieties on Number of Tillers, Weight of Harvested Dried Shallot Bulbs and Weight of Dried Shallots Saved

\begin{tabular}{|l|l|c|c|c|}
\hline No. & Shallot Varieties & Number of tillers (tubers) & $\begin{array}{c}\text { Weight of Harvested Dried } \\
\text { Bulbs (tons/ha) }\end{array}$ & $\begin{array}{c}\text { Dry Bulbs Weight Save } \\
\text { (tons/ha) }\end{array}$ \\
\hline 1. & Bali Karet & $13.40 \mathrm{a}^{1}$ & $14.90 \mathrm{a}^{1)}$ & $12.90 \mathrm{a}^{1}$ \\
\hline 2. & Ampenan & $10.20 \mathrm{~b}$ & $10.40 \mathrm{~b}$ & $8.50 \mathrm{~b}$ \\
\hline 3. & Keta Monca & $9.90 \mathrm{~b}$ & $10.10 \mathrm{~b}$ & $8.30 \mathrm{~b}$ \\
\hline
\end{tabular}

In Table 8 it can be seen that the shallot varieties showed different effects on the number of tillers of shallots, the weight of harvested dry shallots, and the weight of stored dry shallots. The Bali Karet variety showed that the number of tillers, harvested dry onion bulbs, and stored dry shallot bulbs were higher than the Ampenan and Keta Monca varieties.

, the weight of harvested dry shallots and the weight of stored dry shallots. The difference in the effect of shallot varieties is thought to be due to genetic factors of each variety and the influence of environmental conditions of planting. Genetic factors are one of the factors that affect plant growth and yield [42]. The average number of tillers of the Bali Karet variety was $7-14$ higher than the Ampenan variety, 7 - 12 and the Keta Monca variety, 5 -9. The average yield of harvested dry shallot bulbs for the
Bali Karet variety was 14-16 tons/ha, higher than the Ampenan variety, 12 tons/ha and the Keta Monca variety, 11 tons/ha [3]

\section{CONCLUSION}

The results showed that:

1. The application of Trichoderma biourine by spraying the soil surface, spraying seed tubers and spraying on plants 21 days after planting can increase the growth and yield of shallot bulbs.

2. The Bali Karet shallots variety is more resistant to Fusarium wilt disease when compared to the Ampenan and Keta Monca varieties. 


\section{ACKNOWLEDGEMENTS}

Thank you to the Director of Resources of the Directorate General of Higher Education, Research and Technology, the Rector of the University of Mataram and the Chair of the University of Mataram LPPM for providing support in the form of facilities and research funds for the Higher Education Excellence Research Development Scheme (PPUPT) for the 2021 Fiscal Year.

\section{REFERENCES}

[1] Anonim, 2014. Cara Menanam Bawang Merah yang Baik dan Benar. http://diperta.jabarprov.go.id/index.php/subMenu/1156.

[2] Badan Pusat Statistik dan Direktorat Jenderal Hortikultura. 2019. Produksi Bawang Merah, Luas Panen Bawang Merah, dan Produktivitas Bawang Merah Menurut Provinsi Tahun 2015-2019.

[3] Sudantha, I. M., Suwardji, I. G. P. M. Aryana, I. M. A. Pramadya dan I. Jayadi,. 2018. Peningkatan Mutu Benih G0/Bibit Bawang Merah Dengan Teknologi Hayati Untuk Menunjang NTB Sebagai Sentra Benih G0/Bibit Bawang Merah Bersertifikat. Laporan Penelitian Unggulan Strategis Nasional. Direktorat Riset Pengabdian Masyarakat dan Lembaga Penelitian dan Pengabdian Kepada Masyarakat Universitas Mataram, Mataram.

[4] Wiyatiningsih, S. 2003. Kajian asosiasi phytophthora sp. dan Fusarium Oxysporum f. sp. capsici penyebab penyakit moler pada bawang Merah. Maperta. 5:1-6.

[5] Dwi J.A. Setiadi G, 2013. Pengendalian Hama, Penyakit dan Virus Pada Tanaman Bawang Merah Published 09/04/2013. By naissalintang. http://www.kiospertanian.com/pengendalian-hama-penyakitdan-virus-pada-tanaman-bawang-merah/.. Di Unduh 14 Pebruari 2014.

[6] Sudantha, I. M. 2015. Pemanfaatan Bioaktivator dan Biokompos untuk Meningkatkan Kesehatan, Kuantitas dan Kualitas Hasil Bawang Merah. Laporan Penelitian Mandiri Program Magister Pengelolaan Sumberdaya Lahan Kering Program Pascasarjana Unram.

[7] Sudantha, I.M. 2009. Aplikasi Jamur Trichoderma spp (Isolat ENDO-02 dan 04 serta SAPRO-07 dan 09) Sebagai Biofungisida, Dekomposer, dan Bioaktivator Pertumbuhan dan Pembungaan Tanaman Vanili dan Pengembangannya pada Tanaman Hortikultura dan Pangan Lainnya di NTB. Laporan Penelitian Hibah Kompetensi DP2M DIKTI, Mataram.

[8] Perdana, S.N., W.S. Dwi, M. Santoso. 2015. Pengaruh aplikasi biourin dan pupuk terhadap pertumbuhan dan hasil tanaman bawang merah (Allium ascalonicum L.). J. Prod. Tan. 3(6): 457-463.

[9] Sudana, I N., G. N. A. S. Wirya, I G. N. Raka, dan P. Sudiarta.2013. Pemanfaatan Biourin Sebagai Biopestisida dan Pupuk Organik dalam Usaha Budidaya Tanaman Sawi Hijau (Brassica rapa var. parachinensis L) Organik. Laporan Penelitian Hibah Unggulan Perguruan Tinggi. Universitas Udayana, Bali. 31 hal. https://simdos.unud.ac.id/uploads/file riwayat penelitian 1 _dir/c415692b2c81eaef61f28e831f5cc492.pdf. Diunduh pada tanggal 26 Februari 2019.

[10] Sudantha, I. M. 2018. Buku Teknologi Tepat Guna: Penerapan Biofungisida dan Biokompos pada Pertanian Organik. LPPM Unram Press, Mataram. ISBN 978-60253669-9-4. 125 hal.

[11] Sudantha, I. M. 2007. Karakterisasi dan Potensi Jamur Endofit dan Saprofit Antagonistik Sebagai Agens Pengendali Hayati Jamur Fusarium oxysporum f. sp. vanillae Pada Tanaman Vanili di Nusa Tenggara Barat. Disertasi Program Pascasarjana Universitas Brawijaya, Malang. 337 hal.

[12] Sudantha, I. M., Suwardji, dan M. T. Fauzi. 2016. Pemanfaatan Bioaktivator dan Biokompos Hasil Fermentasi Jamur Trichoderma spp. serta Fungi Mikoriza Abuskular Untuk Meningkatkan Kesehatan, Pertumbuhan dan Hasil Bawang Merah. Laporan Penelitian Dana PNBP Unram, Mataram.

[13] Sudantha I M. 2011. Uji aplikasi beberapa jenis biokompos (hasil fermentasi jamur T. koningii isolat Endo-02 dan $T$. harzianum isolat Sapro-07) pada dua varietas kedelai terhadap penyakit layu fusarium dan hasil kedelai. Jurnal Ilmu Pertanian Agroteksos, Fakultas Pertanian Universitas Mataram, Mataram. Vol. 21 No. 1 April 2011.

[14] Sudantha, I. M. dan Suwardji. 2013. Pemanfaatan Biokompos, Bioaktivator dan BiocharUntuk Meningkatkan Hasil Jagung dan Brangkasan Segar Pada Lahan Kering Pasiran Dengan Sistem Irigasi Sprinkler Big Gun. Laporan Penelitian Strategis Nasional, Mataram.

[15] Sudantha, I. M. dan Suwardji, 2014. Pemanfaatan Bioaktivator dan Biokompos (Mengandung Jamur Trichroderma spp. dan Mikoriza) Untuk Meningkatkan Kesehatan, Pertumbuhan dan Hasil Tanaman Kedelai di Lahan Kering. Laporan Hibah Tim Pascasarjana DP2M Dikti, Mataram.

[16] Sudantha, I. M., S. Suwardji, I G.P.M. Aryana, I M. A. Pramadya, I. Jayadi. 2020. The Effect of Liquid Bio Fungicides Dosage Trichoderma spp. against Fusarium Wilt Diseases, Growth and Yield of Onion. Journal of Physics: Conference Series 1594 (2020) 012013. IOP Publishing. doi:10.1088/1742-6596/1594/1/012013.

https://iopscience.iop.org/article/10.1088/17426596/1594/1/012013/meta

[17] Sudantha, IM. and Suwardji. 2016. Growth and Yield of Onion (Allium cepa var. ascalonicum) as CA Result of Addition of Biocompost and Boactivity Fermented with Trichoderma spp. In: The 1st International Conference on Science and Technology (ICST) 2016, 1-2 Desember 2016, Universitas Mataram. http://eprints.unram.ac.id/4603/

[18] Sudantha, I. M., M. Isnaini, W. Astiko, N.M.L. Ernawati. 2018. The Influence of Arbuscular Mycorrhizal Fungi and Bioactivator (containing Trichoderma spp. Fungi and Legundi Leaf Extract) on Fusarium Wilt Diseases and Yield of Onion. CROP AGRO, Jurnal Ilmiah Budidaya, [S.1.], v. 11, n. 2, p. 94-103, Aug. 2018. ISSN 2621-5748. https://www.cropagro.unram.ac.id/index.php/caj/article/vie $\mathrm{w} / 205$. 
[19] Sudantha, I. M., 2013. Patogen Tumbuhan Tular Tanah dan Pengendaliannya. Agra Puji Press, Matram. ISBN: 978979-1025-56-0. 250 hal.

[20] Sudantha, I. M., Suwardji, dan I. G. P. M. Aryana. 2019. Desiminasi Pembuatan Bioaktivator, Biokompos Dan Biourin Limbah Kotoran Sapi Dengan Teknologi Fermentasi Trichoderma dan Aplikasinya Untuk Meningkatkan Hasil Bawang Merah. Laporan Akhir Produk Teknologi yang di Desiminasikan ke Masyarakat Kementerian Riset, Teknologi dan Pendidikan Tinggi Tahun Anggaran 2019.

[21] Latifah, A. Kustantinah, Loekas Soesanto. 2011. Pemanfaatan Beberapa Isolat Trichoderma harzianum Sebagai Agensia Pengendali Hayati Penyakit Layu Fusarium Pada Bawang Merah in Planta. Eugenia Vol.17 No 2. Universitas Jenderal Soedirman.

[22] Alfizar, Marlina and Hasanah. 2011). Upaya Pengendalian Penyakit Layu Fusarium oxysporum Dengan Pemanfaatan Agen Hayati Cendawan FMA dan Trichoderma harzianum. Jurnal Floratek, 6: 8-17.

[23] Windham, M., Y. Elad and R. Baker. 1986. A Mechanism of Increased Plant Growth Induced by Trichoderma spp. Phytopathology 76: 518 - 521.

[24] Salisbury, F. B. and C. W. Ross, 1995. Fisiology Tumbuhan Jilid 3. Perkembangan tumbuhan dan fisiologi Tumbuhan (Terjemahan D. R. Lukman dan Sumaryono). Penerbit ITB Bandung.

[25] Cook and Baker, 1983. The Nature and Practice of Biological Kontrol of Plant phatogens. The American Phytopathol Society Paul MN. 539 P

[26] Arianci, R. 2014. Pengaruh Campuran Kompos Tandan Kosong Kelapa Sawit, Abu Boiler dan Trichoderma terhadap Pertanaman Kedelai pada Sela Tegakan Kelapa Sawit yang Telah Menghasilkan di Lahan Gambut. Jurnal Teknobiologi, 5(1), 21-29.

[27] Triyatno, B. Y., 2005. Potential Multiple Control Agents against Ginger Rhizome Disease. Essay. Faculty of Agriculture, Jenderal Sudirman University. Purwokerto. 48

[28] Yusrinawati, Sudantha dan Astiko. 2017. The Effort of Increasing Growth And Harvest of Local Variety Red Onion With Applications of Some Dose of Indigenous Mycorrhizal And Bioactivator Trichoderma spp. in Dry Land. IOSR Journal of Agriculture and Veterinary Sciensce (IOSRJAVS). Volume 10, Issue 9 Ver. I (September 2017), PP 42$49 \quad$.e-ISSN: 2319-2402,p- ISSN: 2319-2380. http://www.iosrjournals.org/iosr-javs/pages/ 10(9)Version1.html

[29] Sudantha, I M. 2017. Eksplorasi Sumberdaya Alam (Biokompos, Bioaktivator, Biochar dan FMA) Untuk Mengembangkan Tanaman Pangan Sistem Organik Di Lahan Kering. Seminar Nasional MIPA Universitas Nahdlatul Wathan. Mataram. 136-150.

[30] Yudhiarti, S., I. M. Sudantha and M. T. Fauzi. 2020. Effect of Giving Arbuscular Mycorrhizal Fungi (AMF) and Bioactivator Dosage of Trichoderma spp. on the Growth and Products of soybeans (Glycine max L. Merr.). Traektoriâ Nauki $=$ Path of Science 6 (9)

[31] Apzani, W.; I. M. Sudantha, and M. T. Fauzi. 2015. Aplikasi biokompos stimulator Trichoderma spp. dan biochar tempurung kelapa untuk pertumbuhan dan hasil jagung (zea mays 1.) di lahan kering. Jurnal Agroteknologi, [S.1.], v. 9, n. 01, p. 21-35, June 2015. ISSN 2502-4906. Available https://jurnal.unej.ac.id/index.php/JAGT/article/view/3067

[32] Ningsih, D. H., I. M. Sudantha and Suwardji. 2019. Application of Liquid Bioactivator Contains Trichoderma spp. and Elements of Boron (B) as Growth of Growth and Improvement of Red Onion (Allium Cepa L.) Results. International Journal of Multicultural and Multireligious Understanding, 6(6), 509-525.

[33] Prayoba, U. E., \& I.M. Sudantha. 2019. Giving of Biochar and Biocompost to Growth, Results and N Uptake Soybean Plants (Glycyne Max (L) Merr.). International Journal of Environment, Agriculture and Biotechnology, 4(2).

http://journal-

repository.com/index.php/ijeab/article/view/462

[34] Sukartono and I. M. Sudantha. 2016. Agronomic Response of Soybeans and Soil Fertility Status under Application of Biocompost and Biochar on Entisols Lombok, Eastern Indonesia. IOSR Journal of Environmental Science, Toxicology and Food Technology.

[35] Sudantha, I M. and S. Suwardji. 2021. The effect of biocompost Trichoderma spp. tablet in stimulating shallot growth and yield for climate change adaptation. 6th International Conference on Climate Change 2021 IOP Conf. Series: Earth and Environmental Science 824 (2021) 012032 IOP Publishing doi:10.1088/17551315/824/1/012032.

https://iopscience.iop.org/article/10.1088/17551315/824/1/012033/pdf

[36] Sudantha, I M. and S. Suwardji. 2021. Trichoderma biofungicides formulations on shallot growth, yield and fusarium wilt disease resistance. 6th International Conference on Climate Change 2021 IOP Conf. Series: Earth and Environmental Science 824 (2021) 012032 IOP Publishing doi:10.1088/1755-1315/824/1/012032.

https://iopscience.iop.org/article/10.1088/1755$1315 / 824 / 1 / 012032 / \mathrm{pdf}$

[37] [37] Sudantha, I. M., S. Suwardji, I G.P.M. Aryana, I M. A. Pramadya, I. Jayadi. 2020. The Effect of Liquid Bio Fungicides Dosage Trichoderma spp. against Fusarium Wilt Diseases, Growth and Yield of Onion. Journal of Physics: Conference Series 1594 (2020) 012013. IOP Publishing. doi:10.1088/1742-6596/1594/1/012013. https://iopscience.iop.org/article/10.1088/17426596/1594/1/012013/meta

[38] Sudantha, I. M. 2021. Characterization and virulence of Fusarium oxysporum f. sp. cubense cause wilt disease in banana plants and its biological control using endophytic fungi Trichoderma spp. at West Nusa Tenggara, Indonesia. IOP Conference Series: Earth and Environmental Science, Volume 886, 2nd Biennial Conference of Tropical Biodiversity 4-5 August 2021, Makassar, Indonesia. https://iopscience.iop.org/article/10.1088/17551315/886/1/012016/pdf

[39] Sudantha, I M. and S. Suwardji. 2021. Biodiversity of Trichoderma antagonist saprophytic fungi and its use for 
biocontrol of Fusarium wilt disease on shallots at Lombok Island, West Nusa Tenggara, Indonesia. IOP Conference Series: Earth and Environmental Science, Volume 886, 2nd Biennial Conference of Tropical Biodiversity 4-5 August 2021, Makassar, Indonesia.

https://iopscience.iop.org/article/10.1088/1755-

$1315 / 886 / 1 / 012123 / \mathrm{pdf}$

[40] Harjadi, S.S. 1991. Pengantar Agronomi. PT. Gramedia. Jakarta.

[41] Lakitan, B. 2004. Dasar-Dasar Fisiologi Tumbuhan. PT Raja Grafindo Persada. Jakarta.

[42] Darjanto dan Satifah. 1990. Pengetahuan Dasar Biologi Bunga dan Teknik Penyerbukan Silang Buatan. PT Gramedia. Jakarta. 